
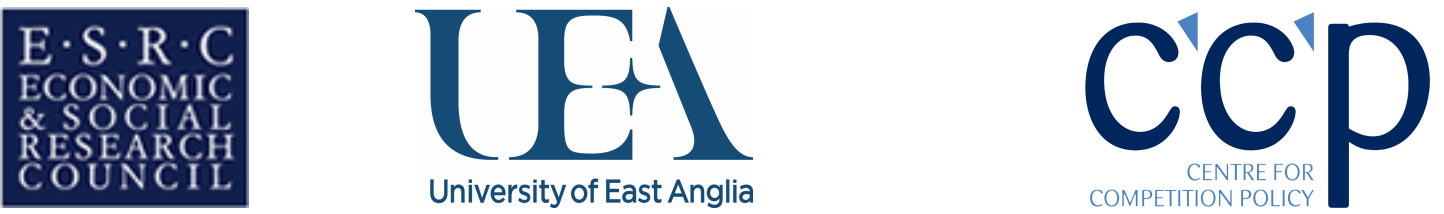

\title{
Beyond the Cartel Law Handbook: How Corruption, Social Norms and Collectivist Business Cultures can Undermine Conventional Enforcement Tools
}

by

\section{Andreas Stephan}

ESRC Centre for Competition Policy \& Norwich Law School, University of East Anglia

\section{CCP Working Paper 08-29}

\begin{abstract}
The combination of leniency programmes, high sanctions, complaints from customers and private actions for damages, has proven very successful at uncovering and punishing cartel agreements in the US. Countless jurisdictions are being encouraged to adopt these 'conventional' enforcement tools, in the absence of an international competition authority. The purpose of this paper is to widen the debate on cartel enforcement by identifying three issues which can undermine their effectiveness in some jurisdictions: (1) Corruption and organised crime; (2) Social norms that are sympathetic to collusive practices; (3) Collectivist business cultures built on personal relationships.
\end{abstract}

\section{September 2008}

JEL Classification Codes: D21, K21, K42, L40, Z1

Keywords: cartels, leniency programmes, enforcement, corruption, organised crime, social norms, collectivism

\section{Acknowledgements:}

The author would like to thank Prof. Morten Hviid and Dr Lindsay Stirton (Manchester) for helpful comments. The usual disclaimer applies. The support of the Economic and Social Research Council is also gratefully acknowledged.

\section{Contact details:}

Andreas Stephan, ESRC Centre for Competition Policy, University of East Anglia, Norwich, NR4 7TJ, UK.

a.stephan@uea.ac.uk 


\section{Introduction}

Cartels have come to be seen as 'cancers on the open market economy'; as the 'supreme evil' of antitrust, and as striking 'at the very heart of the principal virtue of economic activity'. ${ }^{1}$ However, the prohibition and punishment of practices such as price fixing and market sharing is a relatively recent phenomenon in the majority of legal jurisdictions. With the support and guidance of the US Department of Justice, European Commission and international organisations, many are still reforming competition laws and adopting the tools of cartel enforcement which have proved so successful in the US. Characteristically, these include the offer of immunity to the first firm to self-report an infringement and the imposition of heavy sanctions on every other cartel member. ${ }^{2}$ They also include a reliance on customers to report suspected infringements to the competition authority and sue for any damages incurred. ${ }^{3}$ The purpose of this paper is to widen the debate on cartel enforcement, which has thus far focused on the design of the policy tools themselves. Three issues are identified which can undermine the efficacy of the 'conventional' enforcement tools identified above: (1) The paralysing effects of corruption, heightened by under-funding, direct political control and high levels of organised crime; (2) Social norms which are sympathetic to collusive practices, compounded by historical factors such as the past behaviour of governments, and a lack of political support for the stepped up enforcement of new cartel laws; (3) Collectivist business cultures in which agreements are largely built upon personal relationships and trust, partly as a reaction to weak legal systems.

\footnotetext{
${ }^{1}$ M Monti, 'Cartels Why and How? Why should we be concerned with cartels and collusive behaviour?' Speech delivered to $3^{\text {rd }}$ Nordic Competition Policy Conference, Stockholm. September 2000l; Verizon Communications Inc v Law Offices of Curtis V Trinko LLP, 124 S Ct 872, 879 (2004); N Kroes, 'Enforcement of Prohibition of Cartels in Europe' in C Ehlermann and L Atanasiu (eds.), European Competition Law Annual 2006: Enforcement of Prohibition of Cartels (Hart Publishing, Oxford 2006) ${ }^{2}$ For example, in a European case involving the price fixing of beer in Holland, the company Interbrew received immunity for reporting the infringement, while its competitor Heineken was fined €219.3 million. DG Competition Press Release, IP/07/509 (18 April 2007)

${ }^{3}$ There has been a high volume of private action suits in the US, although it is unclear what proportion of these primarily concern a breach of contract. In Europe, private enforcement is currently perceived as weak and the European Commission is making efforts to encourage damage claims. DG Competition, 'White Paper on Damages Actions for Breach of the EC antitrust rules' $\operatorname{COM}(2008)$ 165, 2.4.2008; DI Baker, 'Revisiting History-What Have We Learned About Private Antitrust Enforcement That We Would Recommend To Others?' (2004) 16(4) Loyola Consumer Law Review 379
} 
Cartel enforcement must be understood as an international problem. The boundaries of markets plagued by anticompetitive behaviour do not generally coincide with the borders of legal jurisdictions. Yet competition authorities typically impose sanctions according to the harm caused within their own jurisdictions only. The US and the EU are clearly uncomfortable with the role of international cartel policemen, not least for reasons of comity and respect for jurisdictional sovereignty. Moreover, the Supreme Court ruling in Empagran closed the door for foreign claimants to sue for damages in US courts for harm caused outside US markets. ${ }^{4}$ Owen estimated in 2005 that some 80 per cent of the world's population lived in jurisdictions with weak or no competition policy. ${ }^{5}$ This raises the possibility of under-enforcement, as significant fines are only imposed regularly by a handful of jurisdictions; notably the US and EU. Many international cartels may thus be worth while, especially as they are estimated to typically raise prices by 30 per cent and have the most damaging effects on developing countries. ${ }^{6}$ In the absence of an international enforcement agency, cooperation between competition authorities and harmonisation of competition laws (especially leniency programmes) is thought to be essential to achieving some level of deterrence. ${ }^{7}$ It is also important that local cartels are uncovered and punished as these can be very damaging within individual jurisdictions, especially where there is bid rigging in public procurement. The most active competition authorities in the world have dealt with this challenge by providing encouragement and assistance to countries with no formal cartel enforcement regime in place, spurred on by international bodies such as the OECD, UN, IMF and the World Bank. These countries naturally model their cartel laws and enforcement tools on those in Europe and the US, as these have a proven track record.

\footnotetext{
${ }^{4}$ F. Hoffman-LaRoche, Ltd. v. Empagran S.A. US Supreme Court, 14 June 2004, No 03-724

5 B M Owen, 'Competition policy in emerging economies' (2005) SIEPR Discussion Paper No.04-10 p.4

${ }^{6}$ OECD 'Fighting Hard Core Cartels: Harm, Effective Sanctions and Leniency Programmes' (2002) Reports to the Organization for Economic Co-Operation \& Development; M Levenstein and VY Suslow, 'Contemporary International Cartels and Developing Countries: Economic Effects and Implications for Competition Policy' (2003) Antitrust Law Journal, 71:3

${ }^{7}$ See for example: International Competition Network, 'Co-operation between competition agencies in cartel investigations' (2007) Report to the ICN Annual Conference. Available at:

http://www.internationalcompetitionnetwork.org/media/library/conference 6th moscow 2007/19Reporto nCo-operationbetweencompetitionagenciesincartelinvestigations.pdf (accessed 6 July 2008)
} 
The use of immunity and heavy sanctions as a detection tool (inducing selfreporting) is necessary because of the secretive nature of cartel agreements and the difficulty of establishing when such an arrangement has occurred. Other areas of corporate law enforcement, such as environmental law and the regulation of former state monopolies, see a soft enforcement approach similar to that advocated by Ayers and Braithwaite. ${ }^{8}$ However, whereas it is relatively easy to identify the big polluters and companies within a specific industry, cartelists may potentially exist in any sector - many of which transcend legal jurisdictions. There is thus no convenient checkpoint at which collusion can be detected. The fact is we know very little about the extent to which cartels exist in markets and when they are likely to occur. Economic theory tells us the conditions under which collusion is likely, but policing markets is no easy task as a single investigation can be an intensive drain on competition authorities' limited resources. Customers also play an important role in reporting suspected collusion to the competition authority and suing for damages. ${ }^{9}$ Even if a cartel is detected, it can be very difficult to prove that an infringement has actually occurred without explicit evidence or admissions of guilt. For example, competitors may independently choose to raise their prices over time for a number of legitimate reasons. ${ }^{10}$

Leniency programmes overcome these problems by inducing a firm to produce evidence of an infringement in return for immunity. Subsequent firms to come forward will also usually cooperate in return for a reduced fine. Leniency also encourages cooperation where a cartel is uncovered through investigations alone. Fundamentally, leniency programmes assume that firms are driven purely by economic incentives (the pursuit of cartel profits) that will be undermined by the availability of immunity to one firm only. Deterrence is ostensibly achieved by ensuring that the sanctions and likelihood of detection

\footnotetext{
8 J Ayers and J Braithwaite, Responsive Regulation: Transcending the Deregulation Debate, (OUP New York 1992)

${ }^{9}$ Although high levels of damage suits can negate the effects of a leniency programme, as even immunity will generally provide no protection from such follow-on actions

${ }^{10}$ In Europe, the Court of First Instance's decision in Woodpulp made it clear that circumstantial economic evidence alone could not prove an infringement, unless every other possible explanation for the observed behaviour is successfully rebutted
} 
outweigh the benefits. ${ }^{11}$ It is thus necessary that high sanctions accompany leniency in order to ensure infringements are sufficiently punished and that the offer of immunity is tempting enough to induce self-reporting. However, the ability to impose fines of such a magnitude carries with it enormous responsibility.

\section{Abuse of cartel laws by corrupt and weak institutions}

Cartel enforcement is particularly susceptible to corruption because fines which are criminal in character are normally imposed through an administrative system in which the competition authority acts as both investigator and judge. These authorities are not always independent of direct political control, and normally retain wide discretion in calculating fines and granting leniency. ${ }^{12}$ Hood identifies three forms of corruption, all of which might occur in cartel enforcement: misappropriation, or the pocketing of money intended for enforcement activities; bribery, or the accepting of money given by infringing parties in return for non-performance (failing to investigate) or performance (e.g. granting leniency); and extortion, whereby money has been extracted from unwilling parties with the threat of high fines. ${ }^{13}$ Events in Greece in August 2006 demonstrate how these perverse outcomes are not only a concern in developing countries, but within some member states of the European Union. The director of the Hellenic Competition Commission (HCC) was charged with extortion in relation to a dairy firm under investigation for price fixing. He allegedly used a middle man to threaten MEVGAL S.A. with a $€ 25$ million fine for involvement in a cartel, unless they paid a bribe of €2.5

\footnotetext{
${ }^{11}$ This assumption is largely accepted by the law and economics literature on cartels. It is inspired by the writings of $\mathrm{J}$ Bentham, The Theory of Legislation (Routledge London 1931) and is most notably set out in GS Becker, 'Crime and Punishment: An Economic Approach' (1968) Journal of Political Economy, $16(2), 169$; leniency plays an important role in improving detection rates, as imposing very high fines infrequently is unlikely to encourage desistance and may signal to cartelists what the extent of enforcement avoidance is; SM Sheffrin and PK Triest, 'Can brute force deterrence backfire? Perceptions and attitudes in taxpayer compliance' in J Slemrod (ed.) Why People Pay Taxes: Tax Compliance and Enforcement (UMP 1992) at 12; Kahan (1997) FN111

${ }^{12}$ In relation to the EC, see: A Stephan, 'The Bankruptcy Wildcard in Cartel Cases' (2006) Journal of Business Law, August Issue, 511-534; M Hviid and A Stephan, forthcoming 'The Graphite Electrodes Cartel: Fines that deter?' in B Lyons (ed.), Cases in European Competition Policy: the Economic Analysis (CUP Cambridge 2008)

${ }^{13} \mathrm{C}$ Hood, The Art of the State (OUP Oxford 1998) at 29
} 
million, in which case the company would be granted leniency. The scandal was uncovered when MEVGAL approached a government ministry which initiated a police investigation. The defendants claim the money was an attempted bribe, rather than gains from extortion. ${ }^{14}$ Where corruption is widespread, imposing higher fines (as is the trend in conventional cartel enforcement) may simply allow cartelists and competition regulators to increase their 'gains from trade'. ${ }^{15}$ Higher fines allow corrupt officials greater power to negotiate a bribe, and may entice a greater proportion of officials into accepting a bribe. ${ }^{16}$ Moreover, corruption is more likely in the enforcement of crimes that are not subject to a strong social stigma, and which are largely perceived as victimless. The issue of social norms is discussed in the following section of this paper.

The causes of corruption and how to deal with them are well publicised debates which lie outside the scope of this paper. However, some closely related issues can be identified which have a paralysing effect on cartel enforcement. Firstly, cartel enforcement is resource-intensive and a regulator will not attract leniency applications unless it uncovers (at least) some infringements through investigations alone. This will usually be in response to a complaint from customers. The World Bank notes that competition authorities in developed countries have 75 per cent more staff (relative to the size of the economy) than those in developing countries. In 2002, competition authorities in Colombia and Peru employed fewer than six professionals each to deal with the countries' entire competition regime. ${ }^{17}$ A lack of funding not only makes corruption more likely, but paralyses the effective exercise of investigative powers. ${ }^{18}$ In such a situation, the social cost of having an effective competition authority outweighs any benefits accrued in terms of

\footnotetext{
14 'Corruption Charges Issued', Kathimerini, Athens. 13 Sep 2006 'Bribery Plot Curdles', Athens News, Athens. 15 Sep 2006; Hellenic Competition Commission Press Release. 12 Sep 2006 Available at: http://www.epant.gr/Photos/20060913 press release suspension general.pdf (accessed 01-04-2008); At time of writing, the former HCC directors' trial was still pending, following repeated delays

${ }^{15} \mathrm{~J}$ Chang et al., 'Casual police corruption and the economics of crime: Further details' (2000) Int. Rev. of Law and Economics, 20(1), March

${ }^{16} \mathrm{R}$ Bowles and N Garoupa, 'Casual police corruption and the economics of crime' (1997) Int. Rev. of Law and Economics, 17(1), 75

${ }^{17}$ World Bank (2002) Competition. Ch.7, World Development Report at 142

${ }^{18}$ UN, 2002. The relationship between competition, competitiveness and development. UN Conference on Trade and Development TD/B/COM.2/CLP/30 at 8
} 
cartel deterrence, which are likely to be zero. Brazil has in the past been cited as a typical example of an under-funded competition enforcement regime. It adopted competition laws in 1962, but these remained largely inactive until 1994. In 2001 its Administrative Tribunal for Competition (CADE) had 52 employees dealing with 711 cases, most of which concerned mergers. Insufficient resources meant that cartel investigations could not be properly pursued. Only one cartel case was completed between 1994 and $2000 .^{19}$

The inadequate funding that many competition authorities receive often reflects the motivations behind adopting such policies. Cartel laws can be adopted as part of a broad package of market-oriented liberalisation and structural reforms. They can also be adopted to enhance commercial prestige, to successfully negotiate trade agreements, to attract foreign direct investment, as a pre-requisite of financial assistance from the IMF or World Bank, and in order to increase the prospects of EU membership. ${ }^{20}$ Such motivations do not demonstrate a genuine desire to tackle collusive agreements, especially where many of the infringing firms invest in the countries in question. This competition policy 'for show' is reflected in the typical word for word adoption of provisions such as Article 81 and 82, with little or no attempts to shape policy according to local market conditions. Some smaller economies may, for example, contain markets in which there is naturally only room for one firm, and where it would be inefficient to have a large number of competitors.

Secondly, competition authorities' activities can be paralysed and abused by direct political interference, especially where there is a strong overlap between the political and commercial elite. According to the World Bank, around 40 per cent of competition authorities surveyed in 2002 were under direct government control. ${ }^{21}$ Concentrated ownership of undertakings in countries

\footnotetext{
${ }^{19}$ OECD, 'Challenges / Obstacles faced by competition authorities in achieving greater economic development through the promotion of competition' (2004) CCNM/GF/COMP/WD(2004)4

${ }^{20}$ I De Leon, 'A Market Process Analysis of Latin American Competition Policy' (2000) UNCTAD Regional Meeting on Competition Law and Policy, San Jose, Costa Rica, August; WE Kovacic, 'Designing and implementing competition and consumer protection reforms in transitional economies: perspectives from Mongolia, Nepal, Ukraine and Zimbabwe' (1995) 44 DePaul L. Rev. 1417

${ }^{21}$ World Bank (n 17) at 142
} 
such as Mexico means that anticompetitive practices benefit those with the strongest political influence. ${ }^{22}$ This can occur in democracies as well as dictatorships; in fact Kovacic notes how the latter can be more effective at dealing with anticompetitive conduct. ${ }^{23}$ Where political leaders have direct commercial interests, this is even more troubling. In an extreme example, Indonesian President Suharto granted protection to state sanctioned cartels that benefited firms owned by members of his own family. ${ }^{24} \mathrm{~A}$ reluctance to grant a competition authority a degree of independence may be another reflection of the motivations behind adopting competition laws, for example as a pre-requisite to financial assistance.

Finally, 'competition law enforcement can only be as strong as all law enforcement'. ${ }^{25}$ In a jurisdiction with poor levels of law and order, criminal organisations can fill the administrative void, using the threat of violence to further business interests. This threat provides a far greater incentive to honour a collusive agreement, than the purely economic incentives which we assume can be undermined by the combination of stiff sanctions and generous leniency. The threat of violence can force agreement between competitors, deter entry from new firms, and ensure that no party cheats an agreement by producing more or by lowering prices such as to undercut the cartel. Gambetta and Reuter discuss Sicily as an example of where criminal organisations, unopposed by weak law enforcement and corrupt institutions, have directly controlled collusion between businesses. ${ }^{26}$ As with many criminal organisations in areas of poor law enforcement, they have maintained some popular support by providing 'quasi-public' services that the State has failed to deliver; an obvious example is punishing petty criminals. ${ }^{27} \mathrm{~A}$ more recent example of organised crime maintaining a collusive agreement is the

\footnotetext{
${ }^{22} \mathrm{M}$ Gal, 'The Ecology of Antitrust Preconditions for Competition Law Enforcement in Developing Countries' New York University Law and Economics Working Papers, Year 2004, Paper 10, also in Competition, Competitiveness and Development (UNCTAD 2004) 20-38

${ }^{23}$ WE Kovacic, 'Institutional Foundations for Economic Legal Reform in Transition Economies: The Case of Competition Policy and Antitrust Enforcement' (2001) Chicago Kent Law Review, 77, 265 ${ }^{24} \mathrm{~F}$ Rohertson-Snape, 'Corruption, Collusion and Nepotism in Indonesia' (1999) Third World Quality, 20(3), 89-602

${ }^{27}$ D Gambetta, The Sicilian Mafia: The Business of Private Protection (HUP Cambridge, MA 1993)
} 
South African taxi cartels. ${ }^{28}$ Violence plays a key role in determining how markets are shared, and in erecting barriers to entry for new taxi companies. Sekhonyane and Dugard note the efficacy of violence as a means of suppressing competition and of failed attempts by the South African government to tackle organised crime. ${ }^{29}$ Politicians who have attempted to curb the cartel's power in the past have been threatened and even attacked. Others own taxis controlled by the cartels and so gain from the collusion. Yet South Africa's competition authority is active in pursuing anticompetitive practices in non-violent industries, highlighting how organised crime of the scale seen in Sicily and South Africa needs to be tackled as a separate issue. Garoupa demonstrates how increasing sanctions in order to take on cartels underpinned by violence is likely to lead to greater use of violence. ${ }^{30}$ The regulator may find itself in a competition with the mafia over who is the more frightening. ${ }^{31}$

Thus, 'conventional' cartel enforcement tools of high fines and generous leniency can be abused by corrupt institutions. Their effects can also be paralysed by three closely-related issues: underfunding, direct political control and high levels of organised crime. Corruption and lawlessness in particular must be dealt with as separate issues, ideally before serious cartel enforcement efforts are stepped up. In this context, forcing countries to adopt cartel laws (for example as a pre-requisite for an IMF loan) may be well intentioned, but can be counter-productive in diverting 'scarce national resources away from more important law reform priorities' ${ }^{32}$

\footnotetext{
${ }^{28}$ Cartels battle for supremacy in South Africa's taxi wars, Jeffrey Barbee The New York Times, 17 Sept 2006 http://travel2.nytimes.com/2006/09/17/world/africa/17africa.html (accessed 01-04-2008)

${ }^{29} \mathrm{M}$ Sekhonyane and J Dugard, 'A Violent Legacy: The taxi industry and government at loggerheads' (2004) SA Crime Quarterly No.10, November

${ }^{30}$ N Garoupa, 'The Economics of Organised Crime and Optimal Law Enforcement' unpublished paper. Presented at $14^{\text {th }}$ annual conference of the European Association of Law and Economics, Barcelona, September 1997

${ }^{31}$ The only documented EC cartel case involving violence was French Beef (COMP/C.38.279/F3 OJ [2003] L 209). Farmer members of three beef federations used the threat of violence to compel the slaughterer federations to accept the agreement (at 101)

${ }^{32}$ Kovacic (n 23) at 1200
} 


\section{Social norms as a barrier to enforcement}

Legal enforcement mechanisms cannot function unless they are based on a broad consensus about the normative legitimacy of the rules - in other words, unless the rules are backed by social norms. ${ }^{33}$

Social norms are intrinsically difficult concepts to define, but essentially they 'instinctively inform people's first reaction to a given activity'. ${ }^{34}$ One of the greatest challenges facing any jurisdiction adopting cartel laws is hardening popular attitudes to practices such as price fixing and market sharing. Historically, the treatment of price fixing outside North America has been favourable. Sympathetic social norms make it less likely that customers will report suspected collusive practices to the competition authority. They also raise the danger that businesses will successfully lobby government to oppose any attempts by the regulator to step up enforcement (i.e. increasing fines and leniency). Social norms opposing cartels have the potential not only to overcome these problems, but also to complement sanctions and encourage desistance. Education is an obvious avenue for changing social norms, but educating people about the harmful effects of cartels is not easy.

Unlike conventional crimes such as theft, cartel practices are not universally treated as objectionable or harmful. This is mainly because of the past treatment of such behaviour by governments and the judiciary. It is well known that for most of the $19^{\text {th }}$ and $20^{\text {th }}$ centuries, European governments treated many cartels as furthering the public interest. In Germany, membership of cartels was sometimes compulsory - particularly in times of economic instability when collusive agreements were viewed as a useful way of stabilising spiralling prices. ${ }^{35}$ As recently as ten years ago in the UK, cartels received nothing more than a regulatory slap on the wrist. In addition, English common law has shown a remarkable tolerance of restraints of trade. The long standing principle in Adelaide Steamship is that:

\footnotetext{
${ }^{33}$ E Fehr and U Fischbacker, 'Social norms and human cooperation' (2004) TRENDS in Cognitive Schiences, 8(4), April

${ }^{34}$ EA Posner, 'Law, Economics and inefficient Norms' (1996) 144 Univ. Pa. Law Rev. 1697

${ }^{35} \mathrm{C}$ Harding and J Joshua, Regulating Cartels in Europe: A Study of Legal Control of Corporate Delinquency (OUP Oxford 2003) 76
} 
no contract was ever an offence at common law merely because it was in restraint of trade... The right of an individual to carry on his trade or business in the manner he considers best in his own interests involves the right of combining with others in a common course of action, provided such common course of action is undertaken with a single view to the interests of the combining parties and not with a view to injure others. ${ }^{36}$

In another case, Jones $v$ North. ${ }^{37}$ Sir James Bacon V-C ruled that there was no dishonesty in the act of bid-rigging, describing it as 'very honest'. ${ }^{38}$ These are cases that have never been overruled, and in the recent House of Lords decision in Norris $v$ United States, ${ }^{39}$ they were found to still hold true, at least in relation to conduct preceding the Enterprise Act 2002 which introduced a criminal offence for cartel practices. At the heart of this case law lies a distinction between colluding for the purposes of furthering one's own interests, and colluding with a view to prejudicing another's property. Accordingly, it was held in Norris that cartel practices implemented during the 1990s could not constitute conspiracy to defraud (were not dishonest) unless accompanied by some 'aggravating features' such as fraud or misrepresentation. ${ }^{40}$

The UK experience is not unusual; in many economies adopting competition laws, collusive practices were tolerated and even encouraged in the very recent past. Thus in South Korea, the regulator found itself in the precarious position of imposing fines on a petrochemical cartel that had in the past been encouraged by the South Korean government in order to avoid excessive competition. ${ }^{41}$ Other examples include Brazil where Owen notes the difficulties of pursuing an aluminium cartel originally encouraged by the Brazilian government. ${ }^{42}$ In Japan, industry-wide exemptions to collusive

\footnotetext{
${ }^{36}$ Attorney General of the Commonwealth of Australia v Adelaide Steamship Co Ltd [1913] AC 781, 797 (Mogul Steamship Co Ltd v McGregor, Gow \& Co (1888) 21 QBD 544; (1889) 23; QBD 598 (CA); [1892] AC 25)

37 Jones $v$ North (1875) LR 19 Eq 426

38 lbid., at 429

${ }^{39}$ Norris $v$ Government of the United States of America and others [2008] UKHL 16

$40 \mathrm{lbid}$., at 17; Conspiracy to defraud is a broad English common law offence which hinges on a two part subjective/objective test of dishonesty as set out in $R \vee$ Ghosh [1982] 2 ALL ER 689

41 'Price Fixing is a Serious Crime' The Chosun Ilbo (English Edition), Seoul. 21 Feb 2007 http://english.chosun.com/w21data/html/news/200702/200702210032.html (accessed 01-04-2008)

${ }^{42}$ Owen (n 5) at 27
} 
behaviour as a protectionist measure were not repealed until 1999. In Indonesia, following the economic collapse in 1997, the IMF forced farreaching reforms aimed (in part) at breaking up cartels put in place by the Suharto presidency. The individuals initially given the job of breaking up these practices were the same government officials who had helped set up the cartels in the first place. ${ }^{43}$ Finally, De Leon notes how laws aimed at tackling anticompetitive practices are viewed with particular hostility in formerly socialist Latin American countries, where the free market is popularly viewed with great suspicion. ${ }^{44}$ For many years, governments in such countries intervened through price controls, barriers against foreign competition and encouraging collusion through trade associations. Where social norms are permissive of cartel practices, customers are less likely to complain to the competition authority when they suspect such behaviour is occurring. This makes it difficult for the regulator to maintain a credible threat of uncovering at least some cartels through investigations alone, and may thus have a negative effect on leniency. If the cartel is profitable, then firms will choose to continue colluding until enforcement efforts are stepped up and infringements are seen to be uncovered and punished. Customers will also be far less likely to bring private actions for damages.

A further problem arises where efforts by the competition authority to step up enforcement (by imposing higher fines) are rejected as disproportionate by businesses who then successfully lobby government to oppose such efforts. Christine Parker describes this phenomenon as the 'compliance trap', where there is a lack of popular and political support for the 'moral seriousness' of cartel laws. ${ }^{45}$ She points to the difficulty faced by the Australian Competition and Consumer Commission (ACCC) in raising sanctions during the period 1997-2003. The ACCC had set out to instil a moral message in enforcement 'to change social norms to define cartel behaviour as socially and morally unacceptable'. ${ }^{46}$ Thus, in addition to imposing higher sanctions, the ACCC

\footnotetext{
${ }^{43}$ Rohertson-Snape (n 24) at 601

${ }^{44}$ De Leon (n 20) at 5

${ }^{45}$ C Parker, 'The 'compliance' trap: the moral message in responsive regulatory enforcement' (2006) Law \& Society Review, 40(3), 591-622

46 Ibid., 19-24
} 
employed explicitly moral language aimed at stigmatising cartel behaviour. Businesses reacted angrily to these moves, describing the ACCC's behaviour as 'unfair, unjust and immoral' and expressing outrage at being subject to dawn raids without prior notice. ${ }^{47}$ Without perceived moral seriousness, businesses largely viewed ACCC enforcement efforts as lacking legitimacy, procedurally unfair and as stigmatising otherwise 'ordinary honest business people'. Many businesses successfully lobbied politicians to criticise the ACCC. They also enjoyed substantial support from members of the public. This was in part due to the localised nature of many Australian industries, with employees believing that an attack on their employer was an attack on them. With these firms and their employees operating within specific constituencies, politicians showed a willingness to respond positively. ${ }^{48}$ Political pressure exerted in this way left the competition authority isolated between public scepticism and business hostility on the one hand, and political pressure to revert back to soft enforcement on the other. The ACCC fought off these pressures thanks to the strong leadership of Allan Fels who, upon retiring, expressed some surprise at having lasted so long. ${ }^{49}$

Social norms opposing price fixing can strengthen the deterrent effect of cartel enforcement by encouraging desistance, even where the potential costs of colluding do not clearly outweigh the expected benefits. ${ }^{50}$ There is also empirical evidence to suggest a particularly strong correlation between desistance and an expectation that peers will obey a given law. ${ }^{51}$ Research into tax evasion shows that how a crime is perceived can be as important in achieving deterrence as the probability of detection and size of the sanction. Firstly, a popular stigma attached to the behaviour will add a social cost to legal sanctions. Secondly, popular perceptions can influence personal ethics so that once individuals accept that tax evasion is bad, it is excluded from

\footnotetext{
${ }^{47}$ Comments by David Murray, CEO of Commonwealth Bank; Parker ( $\mathrm{n} 45$ ) at 17

${ }^{48}$ Parker (n 45) at 30

49 'Allan Fels surprised he lasted so long at the ACCC' Australian Associated Press Financial News Wire 29 June 2003; Parker ( $n$ 45) at 31

${ }^{50} \mathrm{D}$ Chong, 'Values versus Interests in the Explanation of Social Interests' (1996) 144 V. Pa. L. Rev. 2079

${ }^{51}$ HG Grasmick and DE Green, 'Legal Punishment, Social Disapproval and Internalization as Inhibitors of Illegal Behaviour' (1980) 71 Journal of Criminal Law \& Criminology 325; DM Kahan, 'Social Influence, Social Meaning and Deterrence' (1997) 83 Virginia Law Review 349, FN18
} 
their behavioural options. ${ }^{52}$ Social stigma may also entail loss of reputation, although this is unlikely to affect upstream firms (typically involved in collusion) who are largely unknown to ordinary members of the public. The customers of such firms (themselves corporations) will have no choice but to continue buying from them, given the concentrated nature of the industry and the lack of available substitutes - the very characteristics that make collusion profitable in the first place.

The development of a popular stigma against price fixing is one of the most challenging tasks faced by competition authorities around the world. Social norms can develop according to a variety of cultural and historical factors. ${ }^{53}$ Information and education can play a key role in shaping them; for example, public information campaigns have completely changed social norms in relation to smoking, wearing seatbelts and drink-driving. However, apart from the historical tolerance of cartels outlined above, there are a number of other obstacles to changing attitudes on price fixing. For one thing, the causal link between cartels and the harm they cause can be somewhat remote. Many cartels are formed in upstream markets (such as raw materials) where their customers (other firms) will simply pass the cost down the production chain. Final consumers will ultimately suffer a loss as a result of such a cartel, but that loss will be shared between a large number of actors; the individual loss may thus be negligible. Competition authorities frequently draw parallels between collusion and theft, but the prejudice or loss caused to another's property as a result of price fixing is not always clear or easily quantifiable. Even conceptualising this loss entails some estimate of what the price would have been, had the cartel not formed. This is no easy task given that market conditions constantly change, impacting firms' costs, and that cartels will not necessarily be successful at raising prices. Even if they were, consumers may pay a cartel-inflated price that they objectively feel is fair for the product in

\footnotetext{
52 M Wenzel, 'The Social Side of Sanctions: Personal and Social Norms as Moderators of Deterrence' (2004) Law and Human Behaviour, 28(5), October, 551-561; supported by previous studies into how crime is perceived including: BE Harcourt, "After the "social meaning turn": implications for research design and methods of proof in contemporary criminal law policy analysis' (2000) Law and Society Review 34, 179-211; R Paternoster, 'The deterrent effect of the perceived certainty and severity of punishment: A review of the evidence and issues' (1987) Justice Quarterly 4, 173-217

${ }^{53}$ Fehr and Fischbacker (n 33)
} 
question. There is no positive deception necessarily involved in cartel practices, which is why it was not deemed to constitute conspiracy to defraud in Norris. ${ }^{54}$

The design of cartel laws is also not conducive to hardening attitudes. Statutory prohibitions such as Article 81 EC are not absolute. Even hardcore cartel practices are capable of satisfying the efficiency defence contained in Article 81(3). ${ }^{55}$ A 2002 report by the World Bank found that only in 12 out of 50 jurisdictions surveyed were cartels per se illegal. ${ }^{56}$ Moreover, Article 81 applies to concerted practices (collusion short of an agreement) as well as hardcore cartels. Where an agreement does not have the object of restricting competition, an economic effects analysis must be undertaken. ${ }^{57}$ Article 81 infringements can thus vary from deliberate and malevolent attempts to distort the market, to inadvertent breaches. Leniency programmes also pose a serious problem. As fines increase to signal the seriousness of cartel practices, the prospect of allowing one cartelist from each infringement to walk away with immunity becomes increasingly unsavoury. When Virgin blew the whistle on their collusion with BA over fuel surcharges in August 2007, the OFT found itself having to defend its leniency policy in the face of media criticism. $^{58}$

\section{Collectivist business practices: 'never fix prices with strangers'}

The previous section outlined how social norms that are permissive of cartels can hinder enforcement, and how a number of obstacles exist to creating a social stigma towards such practices. This section looks at the separate, but not unrelated, issue of collectivist business cultures which are inherently collusive: those built upon personal relationships, reputation, and an

\footnotetext{
${ }^{54}$ A Stephan, 'Survey of Public Attitudes to Price-Fixing and Cartel Enforcement in Britain' CCP Working Paper 07-12

${ }^{55}$ See Commission Notice - Guidelines on the application of Article 81(3) of the Treaty OJ 2004, C101/97

${ }^{56}$ World Bank (n 17) at 133

${ }^{57}$ See for example Case C-234/89 Delimitis v Henninger Brau AG [1991] ECR I-935

${ }^{58}$ For example R Sunderland, 'OFT defends 'snitch' policy' The Observer 5 August, 2007
} 
avoidance of confrontation. These may be capable of maintaining collusive agreements even in the presence of strong social norms opposing collusion, high fines and generous leniency. In many instances they have developed as a reaction to weak legal systems, in particular poor contract law. A study by Hofstede gives some indication of which countries are likely to have collectivist rather than individualist business cultures.

The continued high volume of cartel cases uncovered in the US and the EU suggests that many businesses will attempt to collude, even where knowledge about stepped-up enforcement is commonplace and where efforts have been made to stiffen popular perceptions. One need only look at the FBI secret filming of meetings in the Lysine case, or emails sent in the UK HasbroLittlewoods case. ${ }^{59}$ In this climate of stepped-up enforcement, the central challenge for cartelists is ensuring that their collusive agreement is honoured. As the agreement is illegal, cartelists cannot sue for breach of contract. They must contend with the threat of one cartelist cheating the agreement and undercutting the cartel for personal gain. They also have to contend with the danger of one firm breaking ranks and applying for leniency; an option that becomes more of a risk the greater the difference between the immunity prize and the fine otherwise faced. It is hoped that these conventional enforcement tools are undermining the purely economic incentives that underpin these collusive agreements, inducing self-reporting en masse. Evidence from the chemicals industry would certainly suggest that many cartels are undermined by distrust and that firms are very willing to approach the competition authority when their industry is under investigation, or where the cartel is failing to raise prices. $^{60}$

One way in which adherence to informal agreements can be strengthened is by underpinning economic incentives with personal or collective ties. As the

\footnotetext{
59 "Ian... This is a great initiative that you and Neil have instigated!!!!!!! However, a word to the wise, never put anything in writing, its highly illegal and it could bite you in the arse!!!!" Agreements between Hasbro UK Ltd, Argos Ltd and Littlewoods Ltd fixing the price of Hasbro toys and games CA98/2/2003 [2003] UKCLR 553, para.53; M Furse Competition Law of the EC and the UK (OUP Oxford 2006) at 112 ${ }^{60}$ A Stephan, 'An Empirical Assessment of the European Leniency Notice' (2008) forthcoming in Journal of Competition Law and Economics; CR Leslie, 'Trust, Distrust and Antitrust' (2004) Texas Law Review, 82(3), February, at 545; K Eichenwald, The Informant (Broadway New York 2000) at 155
} 
parties transact over time, their mutual trust builds and their 'business bonds come to resemble familial bonds in which trust in intrinsic'. ${ }^{61}$ Individuals then honour those agreements as a moral obligation, rather than just out of economic gain. The cost of dishonouring the agreement is dishonour, 'quite independent of any legal sanctions'. ${ }^{62}$ In the US there is only very limited evidence of personal ties underpinning collusion in this way. In the citric acid cartel, ADM employed an individual who had close personal ties with individuals within ADM's competitors. ${ }^{63}$ Colette Downie of the Canadian Competition Bureau also notes a general problem of 'social networks play[ing] a role where players in an industry are located in a common geographical area, for example in the same small town or city where the raw resource is being extracted and refined'. ${ }^{64}$ In a study of British shipping cartels in the late $19^{\text {th }}$ and early $20^{\text {th }}$ centuries, Podolney and Scott find that the social status of an entrant owner was found to dissuade the predation behaviour of incumbent cartels. This was especially so where owners were new and had not built up reputations for being dependable co-operators.

Many societies around the world are characterised by close families and intense social interaction. Harmony is often important in such environments; 'confrontation of another person is considered rude and undesirable'. ${ }^{65}$ Group membership of this kind is said to be 'psychologically rewarding', and its resulting loyalty is thought to be strong enough to deter defection from the group even in a one-shot prisoner's dilemma game. ${ }^{66}$ This business culture is inherently collusive and runs counter to the adversarial dynamic which fuels competition, and its resulting benefits. The notion that one should befriend individuals in business and bring them into one's home, can be an explicit

\footnotetext{
${ }^{61}$ Leslie (n 60) at 566

62 Ibid. p.585; J Elster, 'Social Norms and Economic Theory' (1989) Journal of Economic Perspectives, 3(4), at $99-117$

$63 \mathrm{~J}$ Connor, Global Price Fixing (Springer, Berlin 2001) at 131

${ }^{64} \mathrm{C}$ Downie, 'The Fix is in Detecting Cartels in Canada' Speaking at the Australian Competition \& Consumer Commission Cracking Cartels Conference, Sydney, 24 November 2004

${ }^{65} \mathrm{G}$ Hofstede, Cultures and Organisations: Intercultural Cooperation and Its Importance for Survival (Harper Collins 1994) at 58; A Uesugi, 'How Japan is organising enforcement activities against cartels'. Geo. Mason Law Review, 113(12), 353

${ }^{66}$ TR Tyler, 'The Psychology of Procedural Justice: A Test of the Group-Value Model' (1989) 57 Journal of Personality \& Social Psychology 830; Leslie (n 60) at 543; MA O'Connor, 'A socio-economic approach to Japanese Corporate Governance Structure' (1993) 50 Wash \& Lee L. Rev. 1529
} 
social mechanism for ensuring that an agreement is honoured in the absence of strong legal protection. Posner notes,

Where there is a general distrust due to great uncertainty in the environment stemming from unreliable legal, political, commercial and other institutions, there will be greater reliance on personal relations to buffer one from wider insecurities. ${ }^{67}$

A closely-related aspect to this is the history of personal rights. Economic actors are able to pursue individualist interests in jurisdictions such as the US because of strong notions of individual rights, property rights and the enforceability of legally binding contracts. For centuries individual rights as they are understood in the US were alien to many legal systems; not only planned economies such as the USSR, but also countries like Japan. In relation to the Americas, De Leon notes a historical split between English and Spanish colonisation. Spanish colonists (in countries that are today considered to have collectivist business cultures) enjoyed little in the way of individual rights under a feudal system in which everything belonged to, and was paid by, the Spanish crown. By contrast, English settlers in what is now the United States bore financial risks as independent agents. This sparked an entrepreneurial culture built on notions of individual liberties and property rights which were upheld by public institutions. ${ }^{68}$

In China 'in place of western-style law, the Chinese [have relied] on a notion of personal relationship associated with the concept of $L i$. ${ }^{69}$ Unlike substantive rights or detailed written contracts, agreements under this concept are flexible and will change according to the needs of the parties in order to preserve harmony. ${ }^{70}$ The sense of shared identification and interpersonal trust

\footnotetext{
${ }^{67}$ EA Posner, Law and Social Norms (HUP, Harvard 2000) at 91

${ }^{68}$ De Leon (n 20) at 4

${ }^{69}$ GR Butterton, 'Pirates, Dragons and US Intellectual Property Rights in China: Problems and Prospects of Chinese Enforcement' (1996) Arizona Law Review 38, 1081 at 1108

${ }^{70}$ Using an empirical economic study, Lyons shows that where there is the need for flexible contracts between firms, that also enjoy a long term business relationship (therefore a repeated game), expectations and reputation are more important than contracts that govern the present transaction. B Lyons, 'Incomplete Contract Theory and Contracts Between Firms: A Preliminary Empirical Study' (2001) CCR Working Paper 01-1. Available at: http://www.ccp.uea.ac.uk/publicfiles/workingpapers/ ccr01-1.pdf (accessed 01-04-2008); there is also the influential work of Granovetter, who shows how interpersonal ties can facilitate more efficient information exchange than formal ones : MS Granovetter,
} 
(guanxi) underpinning Chinese business agreements can largely be built through trade associations, strongly associated in the West as platforms for collusion. In addition, repeated transactions serve to build personal relationships and reputation through a proven track record of honouring agreements. This requires 'continual social interaction. Social visits, invitations to dinner and the preferment of gifts facilitates this process'. ${ }^{71}$ A tendency for familial links between the families of the contracting partners constitutes an additional bond. The consequences of dishonouring an agreement can be stark and far-reaching. ${ }^{72}$ Apart from the possibility of being ostracised from the business community and connected social network, a loss of guanxi can make it a lot harder to borrow money from banks and may even adversely affect treatment by public authorities. ${ }^{73}$ Parallels can be drawn in this respect with a number of other countries including Greece, those in Latin America, and former communist nations. ${ }^{74}$ In relation to Russia for example, Boots notes how 'the well connected managers and bureaucrats of the Soviet era have become today's corporate elite' by capitalising on their social relationships. ${ }^{75}$

The best empirical insight into where collectivist business cultures are likely to exist is the work of Geerd Hofstede. ${ }^{76}$ His research is largely based on a project he undertook in the early 1970s in which he surveyed the employees of IBM subsidiaries in 64 different countries. His findings have been supported by further studies carried out on students (amongst other groups), and are consistent with much of the earlier literature. ${ }^{77}$ Hofstede identified four independent dimensions of cultural differences (although subsequent studies add to these): power desistance, individualism vs. collectivism, masculinity vs

\footnotetext{
'The Strength of Weak Ties' (1973) The American Journal of Sociology, 78(6), 1360-1380; MS Granovetter, 'Economic Action and Social Structure: The Problem of Embeddedness' (1985) The American Journal of Sociology, 91(3), 481-510

${ }^{71}$ TC Kiong and YP Kee, 'Guanxi Bases, Xinyong and Chinese Business Networks' The British Journal of Sociology, 49(1), Mar 1998, 75, 80

${ }_{72}$ Posner ( $\mathrm{n} 67$ ) at 171; Elster (n 62) at 99

${ }^{73} \mathrm{lbid}$. at 80

${ }^{74}$ S Rose-Ackerman, 'Trust, Honesty, and Corruption: Theories and Survey Evidence from PostSocialist Societies' (2001) unpublished paper. Presented at Workshop on Honesty and Trust in PostSocialist Societies at Collegium Budapest, 25-6 May; Hofstede (n 65) at 61; HC Triandis, The analysis of subjective culture (Wiley, New York 1972).

${ }^{75}$ Hofstede (n 65) at 273

${ }^{76}$ For example, Hofstede (n 65)

77 For example, A Inkeles and DJ Levinson. 'National Character: the study of model personality and sociocultural systems' in G Lindsay and E Aronson (eds.), The Handbook of Social Psychology (Addison-Wesley Reading, MA)
} 
femininity, uncertainty avoidance. It is the second which is interesting for the purposes of this paper. ${ }^{78}$ Hofstede defines Individualism as standing 'for a society in which the ties between individuals are loose: everyone is expected to look after himself or herself and his or her immediate family only'. Collectivism stands for 'a society in which people from birth onwards are integrated into strong, cohesive ingroups, which throughout people's lifetime continue to protect them in exchange for unquestioning loyalty'. His findings echo many of the observations made above in relation to China, in particular by stressing the importance of friendship and family in collectivist cultures, as the basis of transactions. The interests of the 'group' are more important than the interests of the individual. Levels of collectivism or individualism were measured according to the importance IBM employees in each country placed on various 'work goal' items. Hofstede found that individualism generally dominates in Western countries; collectivism is more common in Asian and Latin American countries. Japan takes a middle position but is closer to the latter. South Korea was found to be strongly collectivist.

A controlled experiment by Earley confirmed Hofstede's collectivismindividualism distinction. ${ }^{79}$ Earley took 48 Chinese management trainees and an equal number from the US. They were given 40 separate tasks, some with group goals, others with individual goals, some anonymous, others not. The Chinese trainees worked far better anonymously in groups, while the Americans worked far better individually without anonymity. ${ }^{80}$ The results of Hofstede's study in relation to individualism/collectivism are summarised in Table 1:

\footnotetext{
${ }^{78}$ A discussion of possible implications for cartel enforcement with reference to a combined index of the second and fourth dimensions is contained in: CR Lee 'Cultures and Cartels: Cross-Cultural Psychology for Antitrust Policies. (2003) unpublished paper. Institute for Consumer Antitrust Studies, Loyola University, Chicago

${ }^{79}$ PC Earley, 'Social Loafing and Collectivism: a comparison of the United States and the People's Republic of China' (1989) Administrative Science Quarterly, 34, 565-581

${ }^{80}$ See also Hofstede (n 65) at 84
} 
Table 1: ${ }^{81}$ Individualism Index Values (IDV) for 50 Countries and 3 Regions

\begin{tabular}{|c|c|c|c|c|c|}
\hline Score Rank & $\begin{array}{l}\text { Country or } \\
\text { region }\end{array}$ & IDV Score & Score Rank & $\begin{array}{l}\text { Country or } \\
\text { Region }\end{array}$ & IDV Score \\
\hline $\begin{array}{c}1 \\
2 \\
3 \\
4 / 5 \\
4 / 5 \\
6 \\
7 \\
8 \\
9 \\
10 / 11 \\
10 / 11 \\
12 \\
13 \\
14 \\
15 \\
16 \\
17 \\
18 \\
19 \\
20 \\
21 \\
22 / 23 \\
22 / 23 \\
24 \\
25 \\
26 / 27 \\
26 / 27\end{array}$ & $\begin{array}{l}\text { USA } \\
\text { Australia } \\
\text { Great Britain } \\
\text { Canada } \\
\text { Netherlands } \\
\text { New Zealand } \\
\text { Italy } \\
\text { Belgium } \\
\text { Denmark } \\
\text { Sweden } \\
\text { France } \\
\text { Ireland } \\
\text { Norway } \\
\text { Switzerland } \\
\text { Germany } \\
\text { South Africa } \\
\text { Finland } \\
\text { Austria } \\
\text { Israel } \\
\text { Spain } \\
\text { India } \\
\text { Japan } \\
\text { Argentina } \\
\text { Iran } \\
\text { Jamaica } \\
\text { Brazil } \\
\text { Arab } \\
\text { Countries }\end{array}$ & $\begin{array}{l}91 \\
90 \\
89 \\
90 \\
90 \\
79 \\
76 \\
75 \\
74 \\
71 \\
71 \\
70 \\
69 \\
68 \\
67 \\
65 \\
63 \\
55 \\
54 \\
51 \\
48 \\
46 \\
46 \\
41 \\
39 \\
38 \\
38\end{array}$ & $\begin{array}{c}28 \\
29 \\
30 \\
31 \\
32 \\
33 / 35 \\
33 / 35 \\
33 / 35 \\
36 \\
37 \\
38 \\
39 / 41 \\
39 / 41 \\
39 / 41 \\
42 \\
43 \\
44 \\
45 \\
46 \\
47 / 48 \\
47 / 48 \\
49 \\
50 \\
51 \\
52 \\
53\end{array}$ & $\begin{array}{l}\text { Turkey } \\
\text { Uruguay } \\
\text { Greece } \\
\text { Philippines } \\
\text { Mexico } \\
\text { East Africa } \\
\text { Yugoslavia } \\
\text { Portugal } \\
\text { Malaysia } \\
\text { Hong Kong } \\
\text { Chile } \\
\text { West Africa } \\
\text { Singapore } \\
\text { Thailand } \\
\text { Salvador } \\
\text { South Korea } \\
\text { Taiwan } \\
\text { Peru } \\
\text { Costa Rica } \\
\text { Pakistan } \\
\text { Indonesia } \\
\text { Columbia } \\
\text { Venezuela } \\
\text { Panama } \\
\text { Ecuador } \\
\text { Guatemala }\end{array}$ & $\begin{array}{l}37 \\
36 \\
35 \\
32 \\
30 \\
27 \\
27 \\
27 \\
26 \\
25 \\
23 \\
20 \\
20 \\
20 \\
19 \\
18 \\
17 \\
16 \\
15 \\
14 \\
14 \\
13 \\
12 \\
11 \\
8 \\
6\end{array}$ \\
\hline
\end{tabular}

Generally there is a positive correlation between wealth and individualism, with some exceptions (Japan). Perhaps increased wealth encourages people to break away from the 'group' more, for their relative gains from it have diminished. Thus we might expect South Korea to be substantially less collectivist today than it was when this study was conducted. We can see from Table 1 that the countries where conventional cartel enforcement tools have a proven track record are generally strongly individualist, rather than collectivist: USA, Canada, Australia, and the EU 15 with the notable exceptions Greece and Portugal. Hofstede has noted 'no evidence that the cultures of presentday generations from different countries are converging'. ${ }^{82}$ However, there is some relationship between wealth and individualism, and the World Bank notes a positive correlation between competition enforcement successes and

\footnotetext{
${ }^{81}$ Adapted from Hofstede (n 65) at 53 Table 3.1

82 Hofstede (n 65) at 17
} 
per capita income. ${ }^{83}$ It has also been observed that, although collectivist business cultures continue on a local level, individualist business cultures prevail in international agreements. ${ }^{84}$ This is reflected in US successes against international cartels involving companies from East Asia, as well as Europe and North America. These have been characterised by extreme distrust, with little evidence of strong personal relationships. ${ }^{85}$ Nevertheless, the challenge remains on the domestic level, where collectivist business cultures are likely to continue, even as individual rights and legal institutions strengthen. In Hong Kong, 'traders have come to value transactions based on personal... guanxi as intrinsically superior to those based upon impersonal laws'. 86

Conventional cartel enforcement tools of acting on complaints, imposing high fines and granting generous leniency are likely to be ineffective against collectivist business cultures, where social mechanisms are used to uphold agreements. Coupled with cultures in which confrontation is always avoided because it is considered socially disruptive, these mechanisms also make private enforcement very unlikely. Hofstede's study gives us some indication of which countries are likely to be more collectivist; however a more recent study is needed to better determine the effects of increased wealth over time.

\section{Concluding remarks and policy implications}

The combination of leniency programmes and high sanctions has proven very successful at uncovering and punishing cartel agreements in the US. Complaints from customers who later seek damages from infringing firms

\footnotetext{
${ }^{83}$ World Bank (n 17) at 141

${ }^{84}$ Kiong and Kee (n 71) at 82-88

${ }^{85}$ Leslie (n 60) at 545; Eichenwald (n 60) at 204

${ }^{86}$ Kiong and Kee (n 71) at 83; MH Bond and KK Hawang, 'The Social Psychology of Chinese People' in M H Bond (ed.) The Psychology of Chinese People (OUP Hong Kong 1986)
} 
have complemented these basic enforcement tools. Spurred on by the US Department of Justice, the European Commission and a number of international organisations, countless jurisdictions are being encouraged to adopt these 'conventional' enforcement tools in the absence of an international competition authority. This is considered an important step in achieving some level of effective deterrence against international cartels and punishing local infringements. This paper has identified a number of obstacles which may exist to the universal efficacy of 'conventional' enforcement tools. These obstacles fall outside the economic considerations which typically inform the design of competition policy. Much of the evidence referred to in this paper is anecdotal, but its purpose is to widen the debate on cartel enforcement to include discussions of the environments in which cartel policy is being adopted and applied. Each of the three issues identified require further research and empirical study.

Firstly, the ability to impose high sanctions and grant immunity is susceptible to corruption, especially if regulators tend to be underfunded and are under direct political control. Underfunding is made more likely where jurisdictions are pressured into adopting competition laws, for example as a prerequisite to a development loan or in order to attract foreign investment. ${ }^{87}$ Direct political control is likely to blunt any serious attempts to tackle cartel infringements as the political and commercial elite tend to overlap in many jurisdictions. Where there are high levels of organised crime, conventional leniency and sanctions are unlikely to break collusive agreements built upon a threat of violence. Customers are also far less likely to approach the regulator with a complaint, and increasing sanctions against such cartels may simply lead to an escalation in the threats of violence. It may be counterproductive for pressure to be exerted on jurisdictions to adopt cartel laws, especially as part of a broader package of competition laws. Cartel enforcement is resourceintensive and may divert scarce funds away from more important reforms (for example to the judiciary) which will help tackle the problems of corruption and organised crime.

\footnotetext{
${ }^{87}$ The OECD believes that greater funding will also increase the perceived legitimacy of competition laws. OECD (n 19) at 49
} 
Secondly, social norms may typically be weak or sympathetic towards price fixing outside of North America because such practices have historically been treated favourably. Such popular perceptions do nothing to encourage desistance, and make it less likely that complaints of such practices will be received by the competition authority, or that private enforcement will occur. They also raise the danger that businesses will successfully lobby government to oppose any attempts by the regulator to step up enforcement (higher fines, leniency and possibly imprisonment). Any efforts to step up enforcement through higher fines may be perceived as lacking legitimacy by business communities and their employees. A social stigma associated with cartel practices have the potential not only to overcome these problems, but also to complement sanctions and encourage desistance. Competition authorities have the difficult task of challenging existing attitudes towards cartels, and building social norms which oppose such practices. These challenges are faced even in developed countries such as the UK and Australia. ${ }^{88}$

The difficulty is in disseminating information about the nature and harmful effects of cartels, as well as about prosecutions. Many competition law regimes do not strictly treat cartels as illegal per se and contain very broad prohibitions with an efficiency defence. Moreover, it is difficult to portray cartels as deeply immoral while employing leniency programmes which allow one party to receive immunity and others to benefit from lower fines. A further obstacle is the general difficulty of measuring the harm that has been caused by collusive agreements. For example, the UK media's coverage of the Norris case highlighted the particular difficulties of arousing interest in the price fixing of upstream products such as carbon graphite and other raw materials. The overcharge in such cases is passed on in the production chain and dispersed among a large number of consumers. It is for this reason that competition authorities prefer to pursue cartels that directly affect final consumers, such as airline fuel surcharges, supermarkets and dairy firms. The Australian experience shows that proactive efforts by the regulator can succeed in

\footnotetext{
${ }^{88}$ Stephan (n 54)
} 
overcoming many of these difficulties; challenging prevailing attitudes, encouraging compliance, complaints and leniency applications. ${ }^{89}$ In challenging attitudes, regulators would be advised to take advantage of natural allies in their attempts to harden attitudes. These may include consumer groups and academic institutions. In developing countries, it may also include the foreign educational elite and even foreign corporations, who might give cartel policies legitimacy by adopting local compliance programmes. $^{90}$

Finally, business cultures built upon personal relationships and reputation can underpin agreements and ensure they are honoured. Many have developed as a necessity where there has historically been weak legal protection of individual rights and contracts. Collectivist business cultures may be immune to the carrot and stick strategy offered by cartel enforcement as a means of uncovering infringements. A firm which betrays an agreement in return for immunity in such an environment risks being entirely isolated within the business community. As firms' relationships with their customers will also be built upon personal ties and reputation, it is extremely unlikely that they will sue those companies for damages - particularly if they expect to continue buying from them in the future. Hofstede's study gives us some indication of which jurisdictions are likely to have predominantly collectivist business cultures. The challenge for competition authorities is to create a culture of competition among businesses. This is no easy task in jurisdictions where collectivist business practices have been the norm for hundreds of years. As many have developed out of necessity as a reaction to weak or absent legal institutions, it is important to ensure that contracts and individual rights are granted adequate protection in law. There is some evidence of a trend towards individualist business cultures, especially in international agreements and as wealth increases. However, Hong Kong is an example of where collectivist business cultures persist locally despite increased wealth and strong legal institutions. In response to this challenge, competition authorities

\footnotetext{
${ }^{89}$ Parker (n 45) at 9-10

${ }^{90}$ Kovacic (n 23) at 275; OECD (n 19) at 49; DK Brown, 'Street Crime, Corporate Crime, and the Contingency of Criminal Liability' 149 Univ. Pa. Law. Rev. 1295, at 1301
} 
should adapt to local conditions and innovate policy as they see fit. For example, the South Korean competition authority has for some years offered monetary rewards to individuals, in order to encourage whistle-blowing. ${ }^{91}$

${ }^{91}$ See Korean Federal Trade Commission Press Release 19 July 2005: http://ftc.go.kr/data/hwp/informant reward.doc (accessed 01-04-2008) 